\title{
Karyotype diversity and 2C DNA content in species of the Caesalpinia group
}

\author{
Polliana Silva Rodrigues ${ }^{1}$, Margarete Magalhães Souza ${ }^{1}$, Cláusio Antônio Ferreira Melo', \\ Telma Nair Santana Pereira ${ }^{2}$ and Ronan Xavier Corrêa ${ }^{1 *}$
}

\begin{abstract}
Background: The Leguminosae family is the third-largest family of angiosperms, and Caesalpinioideae is its secondlargest subfamily. A great number of species (approximately 205) are found in the Caesalpinia group within this subfamily; together with these species' phenotypic plasticity and the similarities in their morphological descriptors, make this a complex group for taxonomic and phylogenetic studies. The objective of the present work was to evaluate the karyotypic diversity and the 2C DNA content variation in 10 species of the Caesalpinia group, representing six genera: Paubrasilia, Caesalpinia, Cenostigma, Poincianella, Erythrostemon and Libidibia. The GC-rich heterochromatin and $45 \mathrm{~S}$ rDNA sites (which are used as chromosome markers) were located to evaluate the karyotype diversity in the clade. The variation in the 2C DNA content was determined through flow cytometry.

Results: The fluorochrome banding indicated that the chromomycin $\mathrm{A}_{3}{ }^{+} / 4{ }^{\prime}, 6$-diamidino-2-phenylindole ${ }^{-}$blocks were exclusively in the terminal regions of the chromosomes, coinciding with 455 rDNA sites in all analyzed species. Physical mapping of the species (through fluorescence in situ hybridization) revealed variation in the size of the hybridization signals and in the number and distribution of the $45 \mathrm{~S}$ rDNA sites. All hybridization sites were in the terminal regions of the chromosomes. In addition, all species had a hybridization site in the fourth chromosome pair. The 2C DNA content ranged from $1.54 \mathrm{pg}$ in Erythrostemon calycina to $2.82 \mathrm{pg}$ in the Paubrasilia echinata large-leaf variant. The Pa. echinata small-leaf variant was isolated from the other leaf variants through Scoot-Knott clustering.
\end{abstract}

Conclusions: The chromosome diversity and the variation in the 2 C DNA content reinforce that the actual taxonomy and clustering of the analyzed taxa requires more genera that were previously proposed. This fact indicates that taxonomy, phylogeny and cytoevolutionary inference related to the complex Caesalpinia group have to be done through integrative evaluation.

Keywords: Caesalpinioideae, Flow cytometry, $\mathrm{CMA}_{3}{ }^{+} / \mathrm{DAPI}^{-}$, Fluorescent in situ hybridization, Pau-Brasil

\section{Background}

Leguminosae is the third-largest family among angiosperms [1], and Caesalpinioideae, its second-largest subfamily, is represented by about 170 genera, many of them with complex and confused taxonomies. This subfamily's phenotypic plasticity is a challenge for taxonomies that are based on morphology [2]. This group commonly occurs in Brazil, which is home to about 790 described species [3, 4]. The Caesalpinia group within the Caesalpinioideae subfamily is a pantropical clade that presents

\footnotetext{
* Correspondence: ronanxc@uesc.br

'Departamento de Ciências Biológicas, Centro de Biotecnologia e Genética, Universidade Estadual de Santa Cruz, Rodovia Jorge Amado, km 16, CEP, Ilhéus, BA 45662-900, Brazil

Full list of author information is available at the end of the article
}

about 205 pantropical species [5], including important Brazilian species that are threatened with extinction [6].

Taxonomic and phylogenetic changes have been done for some species and genera from Leguminosae, including the clustering of taxa in a new genetic system for the Caesalpinia group [5]. The major problem in the Caesalpinia clade taxonomy and its phylogenetic classification relates to morphological similarities, as there is little variation for some descriptors [7]. Solving this problem requires a broad mode of analysis for the taxa characterization $[8,9]$, which has been helpful for the systematic distribution and taxonomy of the Caesalpinia group $[10,11]$.

The banding obtained from the application of chromomycin $\mathrm{A}_{3}\left(\mathrm{CMA}_{3}\right)$ and 4',6-diamidino-2-phenylindole 
(DAPI) fluorochromes, and from the localization of $45 \mathrm{~S}$ rDNA sites using the fluorescence in situ hybridization (FISH) technique, has been used to identify specific sites; the positions and sizes of such tags may be useful as cytological markers. These data allow us to define the location and quantity of the chromosome markers that are commonly observed in a group of species, as well as the specific chromosome pattern of the markers for each species [12].

Flow cytometry has been used in biosystematics analyses, mainly to provide results regarding nuclear DNA content and, consequently, the level of ploidy. This allows for better species detection and delimitation, which is helpful in the study of a particular genus's phylogenetic relationships and evolutionary characteristics [13].

Previous studies in which fluorochrome staining was applied to the Caesalpinioideae subfamily revealed interand intraspecific differences. The heterochromatic blocks observed $\left(\mathrm{CMA}_{3}{ }^{+} / \mathrm{DAPI}^{-}\right)$were distributed in regions proximal to the nuclear organizer regions, but the presence of $\mathrm{CMA}_{3}{ }^{+} / \mathrm{DAPI}^{-}$blocks was also observed in previous studies [14]. The DNA content indicated the existence of intra- and interspecific variability in some genera within Fabaceae [15-17]. However, these analyses included only one DNA-content analysis for a species of the genus Caesalpinia (Caesalpinia crista) [17].

This study aimed to evaluate the karyotype diversity in 10 species (representing six genera) of the pantropical Caesalpinia clade, using the location of GC-rich heterochromatin and the number and position of $45 \mathrm{~S}$ rDNA sites. In addition, $2 \mathrm{C}$ DNA content was quantified using flow cytometry.

\section{Methods}

\section{Botanical material and pretreatment}

Seeds of 10 species of the Caesalpinia group were collected from several locations in the state of Bahia in Brazil (Table 1). The seeds were randomly collected, with the name of obtaining as many species from the state as possible. After field collection, the seeds were treated with Captan $\left(\mathrm{Fersol}^{\circ}\right)$ fungicide and germinated on moistened filter paper in a humid chamber at room temperature. Root tips of approximately $3 \mathrm{~mm}$ in length were collected shortly after germination and pretreated with an antimitotic solution of $0.002 \mathrm{M}$ 8-hydroxyquinoline for $6 \mathrm{~h}$; the root tips were then washed twice in distilled water, dried on filter paper fixed in Carnoy I (3:1 glacial acetic acid to absolute ethanol, $v / \mathrm{v}$ ) [18] for $2 \mathrm{~h}$ at room

Table 1 Estimates of nuclear genome size (2C DNA content) for Caesalpinia group

\begin{tabular}{|c|c|c|c|}
\hline Species & Collect site & $2 C(p g)^{a}$ & $\mathrm{CV} \%$ \\
\hline Paubrasilia echinata (Lam.) E. Gagnon, H.C. Lima \& G.P. Lewis SV (pau-brasil or brazilwood) & $\begin{array}{l}\text { Ilhéus/BA } \\
14^{\circ} 39^{\prime} 09^{\prime \prime} \text { S. 39 10' 10" Wo. }\end{array}$ & $2.76^{\mathrm{B}}$ & 5.25 \\
\hline Pa. echinata $\mathrm{MV}^{\mathrm{b}}$ & $\begin{array}{l}\text { Una/BA } \\
15^{\circ} 17^{\prime} 36^{\prime \prime} \text { S. } 39^{\circ} 04^{\prime} 31^{\prime \prime} \text { Wo. }\end{array}$ & $2.81^{\mathrm{A}}$ & 4.67 \\
\hline Pa. echinata $\mathrm{LV}^{\mathrm{b}}$ & $\begin{array}{l}\text { Una/BA } \\
15^{\circ} 17^{\prime} 36^{\prime \prime} \text { S. } 39^{\circ} 04^{\prime} 31^{\prime \prime} \text { Wo. }\end{array}$ & $2.82^{\mathrm{A}}$ & 4.52 \\
\hline Caesalpinia pulcherrima (L.) Sw. & $\begin{array}{l}\text { Ithéus/BA } \\
14^{\circ} 39^{\prime} 09^{\prime \prime} \text { S. } 39^{\circ} 10^{\prime} 10^{\prime \prime} \text { Wo. }\end{array}$ & $1.63^{\mathrm{E}}$ & 5.80 \\
\hline Cenostigma macrophyllum Tul. & $\begin{array}{l}\text { Ibotirama/BA } \\
12^{\circ} 0.9^{\prime} 19.5^{\prime \prime} \text { S. } 43^{\circ} 10^{\prime} 03.9^{\prime \prime} \text { Wo. }\end{array}$ & $1.83^{\mathrm{D}}$ & 6.65 \\
\hline Poincianella pyramidalis (Tul.) L. P. Queiroz & $\begin{array}{l}\text { Bom Jesus da Lapa/BA } \\
13^{\circ} 19^{\prime} 0.9^{\prime \prime} \text { S. } 43^{\circ} 20^{\prime} 14.8^{\prime \prime} \text { Wo. }\end{array}$ & $1.92^{\mathrm{C}}$ & 8.03 \\
\hline Po. laxiflora (Tul.) L.P. Queiroz & $\begin{array}{l}\text { Bom Jesus da Lapa/BA } \\
13^{\circ} 19^{\prime} 0.9^{\prime \prime} \text { S. } 43^{\circ} 20^{\prime} 14.8^{\prime \prime} \text { Wo. }\end{array}$ & $1.90^{\mathrm{C}}$ & 6.65 \\
\hline Po. microphylla (Mart. ex. G. Don) L.P. Queiroz & $\begin{array}{l}\text { Xique-Xique/BA } \\
10^{\circ} 49^{\prime} 19^{\prime \prime} \text { S. } 42^{\circ} 43^{\prime} \text { 51" Wo. }\end{array}$ & $1.88^{\mathrm{C}}$ & 7.35 \\
\hline Po. pluviosa (DC.) L. P. Queiroz & $\begin{array}{l}\text { Ithéus/BA } \\
14^{\circ} 39^{\prime} 09^{\prime \prime} \text { S. } 39^{\circ} 10^{\prime} 10^{\prime \prime} \text { Wo. }\end{array}$ & $1.87^{\mathrm{C}}$ & 6.28 \\
\hline Po. bracteosa (Tul.) L.P. Queiroz & $\begin{array}{l}\text { Oliveira dos Brejinhos/BA } \\
12^{\circ} 19^{\prime} 01^{\prime \prime} \text { S. } 42^{\circ} 53^{\prime} 45^{\prime \prime} \text { Wo. }\end{array}$ & $1.92^{c}$ & 5.95 \\
\hline Erythrostemon calycina (Benth.) L.P. Queiroz & $\begin{array}{l}\text { Livramento de Nossa Senhora/BA } \\
13^{\circ} 39^{\prime} 07.6^{\prime \prime} \text { S. } 41^{\circ} 50^{\prime} 45.9^{\prime \prime} \text { Wo. }\end{array}$ & $1.54^{F}$ & 6.75 \\
\hline Libidibia ferrea (Mart. Ex Tul.) L.P. Queiroz & 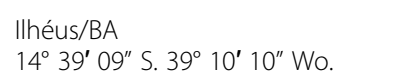 & $1.60^{\mathrm{E}}$ & 9.53 \\
\hline
\end{tabular}

(CV\%) Coefficient of variation

${ }^{a}$ The averages for the 2C DNA followed by the same letter did not differ statistically from one another by the Scott-Knott group at $0.05 \%$ with DMS: 0.0647

${ }^{b}$ During the duration of this study seeds of the medium and large variants have not been found and cytometry analyses were performed on seedlings obtained by donation 
temperature, and maintained at $-20{ }^{\circ} \mathrm{C}$ until the time of use. After radicles were collected, the seedlings were planted in $2 \mathrm{~kg}$ bags with organic soil and monitored in a greenhouse, resulting in matrix plants for the cytogenetic characterization.

\section{Preparation of slides and banding with $\mathrm{CMA}_{3}$ and DAPI fluorochromes}

For the localization of base regions specific to GC and $\mathrm{AT}$, the fluorochromes $\mathrm{CMA}_{3}$ and DAPI were used in a double-staining process. Distamycin A solution was added to the cytological preparation. This protocol followed the one proposed by Guerra and Souza [19], with some modifications. The slides were prepared through enzymatic digestion with $2 \%$ cellulase and $20 \%$ pectinase for $1 \mathrm{~h}$; this was followed by maceration in a drop of $45 \%$ acetic acid and then by freezing in liquid nitrogen to remove the cover slip. The slides containing the cytological preparations were aged for 3 days at room temperature, after which $0.25 \mathrm{mg}^{-1}$ of $\mathrm{CMA}_{3}$ was added for $1 \mathrm{~h}$; this was followed by washing with distilled water and air-drying. Next, $0.1 \mathrm{mg}^{-1}$ distamycin A was added for $30 \mathrm{~min}$, followed by another round of washing with distilled water and air-drying. Finally, DAPI was added for $30 \mathrm{~min}$, followed by a last round of washing in distilled water and air-drying. The slides were assembled with $20 \times 20 \mathrm{~mm}$ cover slips with 1:1 glycerol/Mcllvaine medium $(v / v)$, plus $2.5 \mathrm{mM} \mathrm{MgCl}_{2}$. After the application of the double staining, the slides were aged for another three days before analysis with epifluorescence microscopy.

\section{Fluorescent in situ hybridization}

The application of FISH was performed following the protocol developed by Souza et al. [20], with some modifications, such as eliminating the pretreatment of the slides and adding digestion with pepsin (for better interference of the cytoplasm and cellular walls). The cytological preparations were digested with RNAse $(100 \mu \mathrm{g} / \mathrm{ml})$ and washed twice in 2 xSSC (salt, sodium citrate) for $5 \mathrm{~min}$. Next, $50 \mu \mathrm{l} \mathrm{HCl}(10 \mathrm{mM})$ was added and incubated for $5 \mathrm{~min}$ at room temperature. After removal of the cover slip, $50 \mu \mathrm{L}$ of pepsin solution was added $(0.75 \mu \mathrm{L}$ of pepsin and $49.25 \mu \mathrm{L} \mathrm{HCl}, 10 \mathrm{mM})$, and the slide was kept in a humid chamber at $37^{\circ} \mathrm{C}$ for $20 \mathrm{~min}$. Next, the following steps were carried out: two washes with $2 x S S C$ ( 5 min each); incubation in $4 \%$ paraformaldehyde for $10 \mathrm{~min}$; two washes with $2 \mathrm{xSSC}$ ( 5 min each); and dehydration in an alcoholic series (70\% ethanol and 95\% ethanol; 5 min each). The slide was then air-dried for at least $30 \mathrm{~min}$. The hybridization mixture was composed of $100 \%$ formamide $(7.5 \mu \mathrm{L}), 50 \%$ dextran $(3.0 \mu \mathrm{L}), 20 x S S C(1.5 \mu \mathrm{L}), 10 \%$ sodium dodecyl sulfate $(0.2 \mu \mathrm{L})$ and the $45 \mathrm{~S}$ probe $(2.8 \mu \mathrm{L})$. This mix was heated in a thermocycler at $75{ }^{\circ} \mathrm{C}$ for $10 \mathrm{~min}$, transferred to ice for at least $2 \mathrm{~min}$ and then placed on a slide, which was then denatured in a thermocycler at $75^{\circ} \mathrm{C}$ for $10 \mathrm{~min}$ and placed in a humid chamber at $37^{\circ} \mathrm{C}$ overnight. For the post-hybridization baths, the slide was washed with $2 \mathrm{xSSC}$ at room temperature, followed by two washes in $2 \mathrm{xSSC}$ at $42{ }^{\circ} \mathrm{C}$ ( $5 \mathrm{~min}$ each), two washes in $0.1 \mathrm{xSSC}$ at $42{ }^{\circ} \mathrm{C}$ (5 min each), two washes in $2 x S S C$ at $42{ }^{\circ} \mathrm{C}(5 \mathrm{~min}$ each) and one wash in $4 \times \mathrm{xSC} / 0.2 \%$ Tween 20 at room temperature ( $5 \mathrm{~min}$ ). For detection, $50 \mu \mathrm{l}$ of $5 \%$ BSA was applied to the slide for $10 \mathrm{~min}$ at room temperature, an antibody solution containing $0.7 \mu \mathrm{L}$ of avidin-fluorescein isothiocyanate and $19.3 \mu \mathrm{L}$ of $5 \%$ BSA was then added to the slide, which was kept in a dark, humid chamber for $1 \mathrm{~h}$ at $37^{\circ} \mathrm{C}$. Three washes were performed in $4 \mathrm{xSSC} / 0.2 \%$ Tween 20 at room temperature, while still in the dark. Excess $4 x$ SSC/0.2\% Tween 20 was removed with a blade rinse in $2 \mathrm{xSSC}$, and slide assembly was completed with $15 \mu \mathrm{L}$ of DAPI-conjugated Vectashield ${ }^{\circ}$ (Vector ${ }^{\bullet}$ Laboratories). The slides were refrigerated in a dark container for at least $24 \mathrm{~h}$. Blade analysis was performed using the Olympus ${ }^{\circ}$ BX41 fluorescence microscope; the images were captured with a DP25 digital camera and DP2-BSW software from Olympus. The overlap of the images and the drawing of the boards were completed using Adobe Photoshop ${ }^{\circ}$ software.

\section{Analysis of the 2C DNA}

Five plants of each analyzed species were used in the analysis of the $2 \mathrm{C}$ DNA. For this, five leaves of each species were sampled for the analysis. The species Zea mays CV Kukurice (with $2 \mathrm{C}=5.43 \mathrm{pg}$ of DNA) and Glycine $\max$ L. (with $2 \mathrm{C}=2.50 \mathrm{pg}$ of DNA) [21] were used as internal standards to estimate the species' genome sizes. The Zea mays species was used as an internal standard for the DNA content of all species except Poincianella pluviosa, for which Glycine max was used as the standard. Suspensions of intact nuclei were prepared using the Cystain PI Absolut P kit (Partec ${ }^{\circ}$ ). About $17 \mathrm{mg}$ of leaf tissue from the target species and $20 \mathrm{mg}$ of leaf tissue from the standard were minced simultaneously on a slide in Petri dish with $1 \mathrm{~mL}$ of extraction buffer. The suspension material was filtered through a nylon mesh screen of $50 \mu \mathrm{m}$. Then, $2 \mathrm{~mL}$ of solution containing RNAse and propidium iodide was added, and the material was incubated in a light-protected vessel for at least $30 \mathrm{~min}$ at room temperature. The evaluation of the $2 \mathrm{C}$ nuclear DNA was conducted using the Partec ${ }^{\circ}$ PAII flow cytometer. The gain parameter was adjusted so that the peak for the nuclei of target species G1 was positioned over channel 50. At least 10,000 nuclei were analyzed for each sample. The fluorescence intensity of the nuclei, after staining with propidium iodide, was analyzed at rates of 20-50 nuclei/s. The positions of the peaks, their areas and their coefficients of variation were obtained 
from the cytometer. The size of the nuclear genome was calculated according to Dolezel [22]:

$$
\begin{aligned}
2 \mathrm{CDNA}= & \frac{\text { Average peak } \mathrm{G} 0 / \mathrm{G} 1 \text { for Caesalpinia }}{\text { Average peak G0/G1 for standard }} \\
& \text { x 2C DNA standard }(\mathrm{pg})
\end{aligned}
$$

Analysis of variance (ANOVA) was used for the evaluation of significant differences in the flow cytometry data using a completely randomized design and five repetitions for each species. Additionally, the mean of the $2 \mathrm{C}$ DNA was clustered using Scott-Knott clustering. The ANOVA and the mean clustering were done using Sisvar software [23]. The editing of the Partec ${ }^{\circ}$ flow cytometer histograms was carried out using Corel Draw $^{\circ}$ X7 software.

\section{Results}

Localization of GC-rich heterochromatin

The location of GC-rich heterochromatin using base-specific fluorochromes revealed $\mathrm{CMA}_{3}{ }^{+} / \mathrm{DAPI}^{-}$terminal blocks in all analyzed species. However, $\mathrm{CMA}_{3}{ }^{+}$pericentromeric blocks were also observed in metaphase chromosomes in Libidibia ferrea and Po. microphylla (Figs. 1 and 2). In general, the terminal heterocyclic blocks were of distinct sizes. $\mathrm{CMA}_{3}{ }^{+} /$ $\mathrm{DAPI}^{-}$terminal blocks were observed in two chromosome pairs of Cenostigma macrophyllum, Po. pluviosa, Caesalpinia pulcherrima and $\mathrm{Pa}$. echinata. Three chromosome pairs with $\mathrm{CMA}_{3}{ }^{+} / \mathrm{DAPI}^{-}$terminal blocks were observed in Po. bracteosa, Po.laxiflora, Po. microphylla and $L$. ferrea. Erythrostemon calycina had seven chromosomes with $\mathrm{CMA}_{3}{ }^{+} / \mathrm{DAPI}^{-}$terminal blocks. The highest number of $\mathrm{CMA}_{3}{ }^{+} / \mathrm{DAPI}^{-}$terminal blocks was observed in Po. pyramidalis, which had four chromosome pairs with GC-rich heterochromatic blocks.
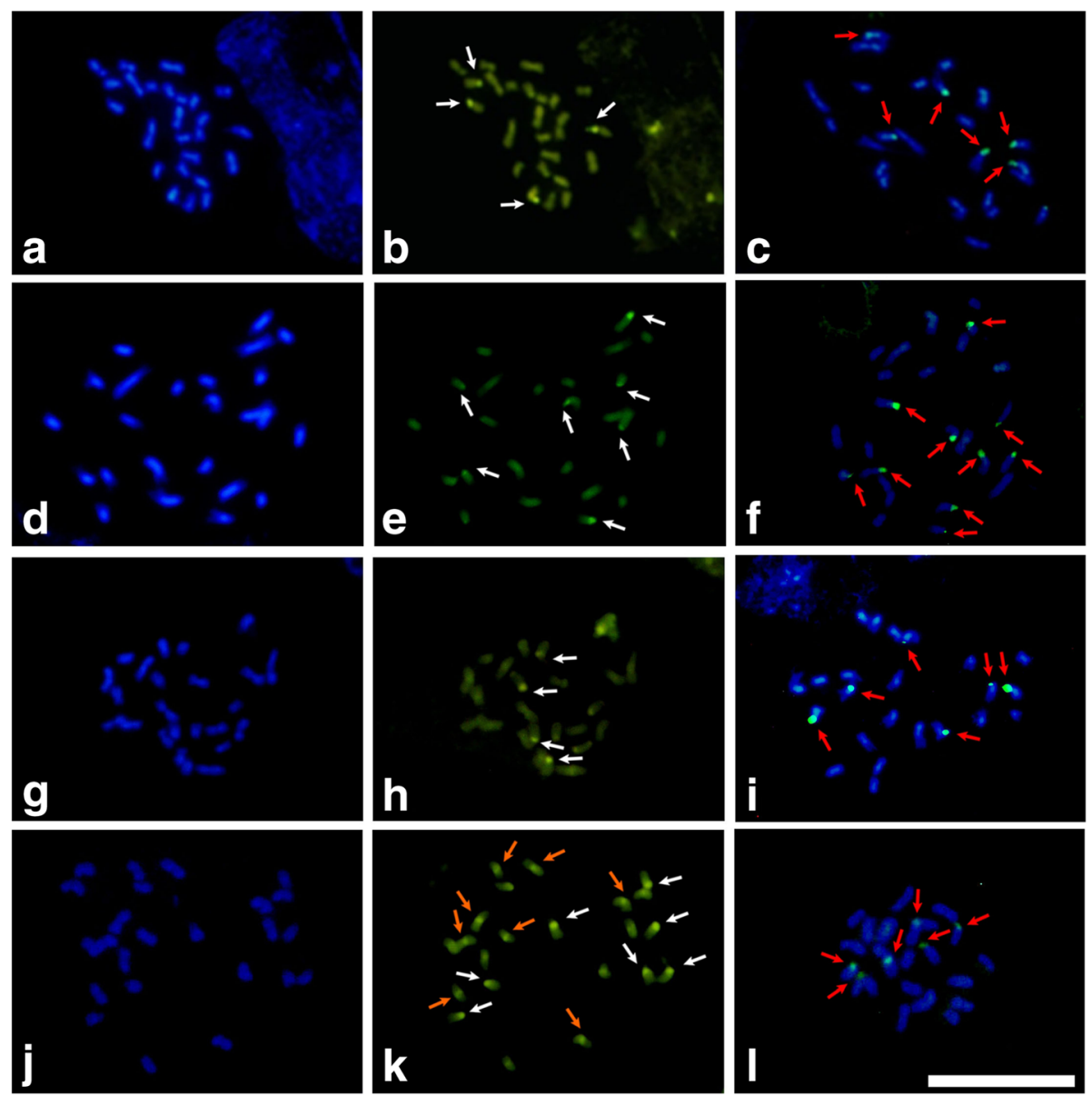

Fig. 1 Application of fluorochromes in the Caesalpinia group. The fluorochromes DAPI $(\mathbf{a}, \mathbf{d}, \mathbf{g}, \mathbf{j})$ and $\mathrm{CMA}_{3}(\mathbf{b}, \mathbf{e}, \mathbf{h}, \mathbf{k})$, as well as the FISH (c, $\left.\mathbf{g}, \mathbf{i}, \mathbf{l}\right)$ with a probe for 455 rDNA on metaphase chromosomes. a - c Cynostigma macrophyllum, (d - $\mathbf{f}$ ) Erythrostemon calycina, (g - i) Poincianella pluviosa and (j- I) Libidibia ferrea. White arrows indicate $\mathrm{CMA}_{3}{ }^{+} / \mathrm{DAPl}^{-}$blocks, orange arrows indicate $\mathrm{CMA}_{3}{ }^{+}$blocks, and red arrows indicate $45 \mathrm{~S}$ rDNA sites; a bar is $10 \mu \mathrm{m}$ 

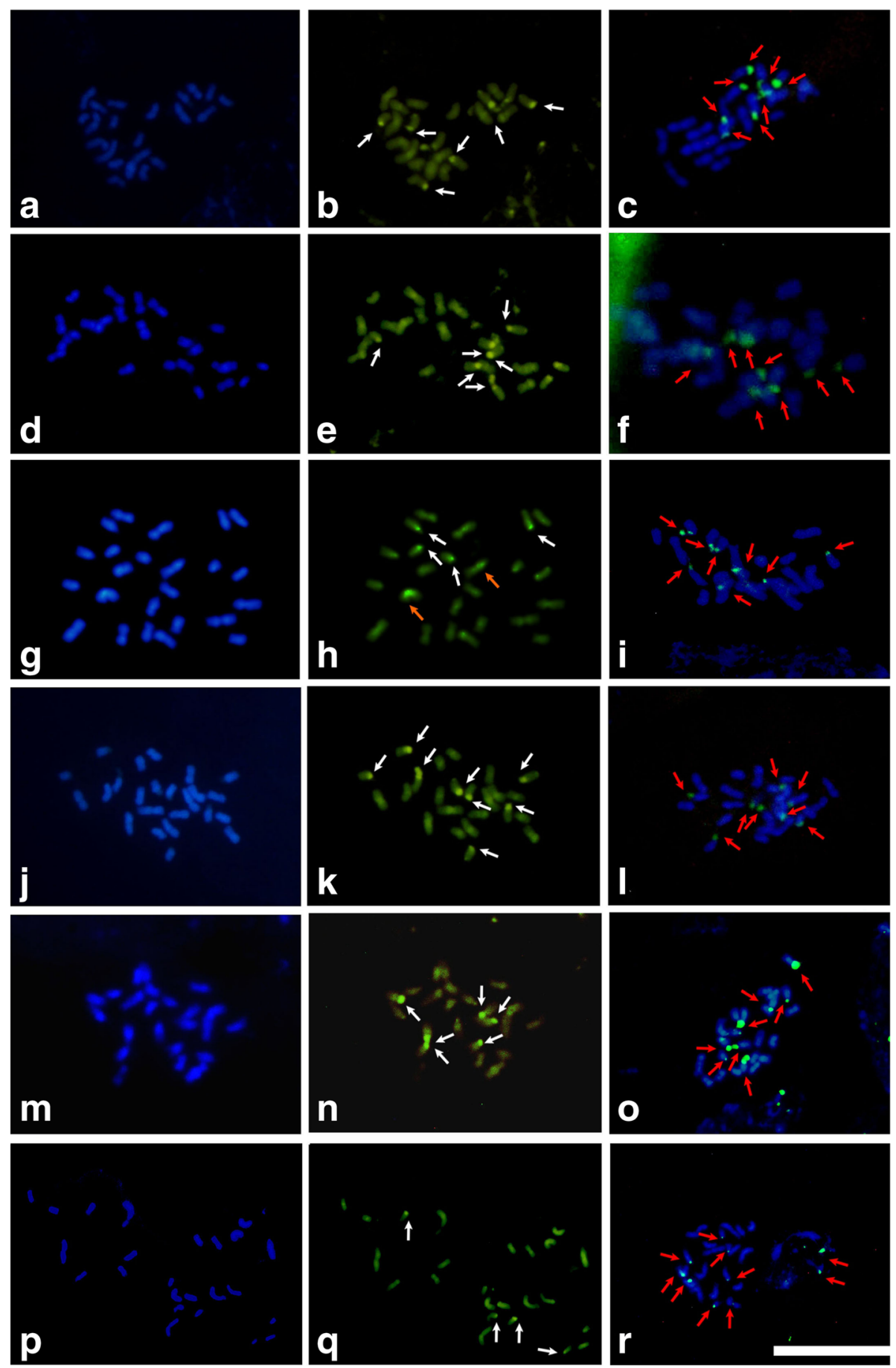

Fig. 2 Application of fluorochromes in the Caesalpinia group. The fluorochromes DAPI $(\mathbf{a}, \mathbf{d}, \mathbf{g}, \mathbf{j}, \mathbf{m}, \mathbf{p})$ and $\mathrm{CMA}_{3}(\mathbf{b}, \mathbf{e}, \mathbf{h}, \mathbf{k}, \mathbf{n}, \mathbf{q})$, as well as the FISH (c, g, i, l, o, r) with a probe for 455 rDNA on metaphase chromosomes. a - c Poincianella bracteosa, (d - f) Po. laxiflora, ( $\mathbf{g}$ - i) Po. microphylla, (j- I) Po. pyramidalis $(\mathbf{m}-\mathbf{o})$, Caesalpinia pulcherrima and $(\mathbf{p}-\mathbf{r})$ Paubrasilia echinata (SV). White arrows indicate $\mathrm{CMA}_{3}{ }^{+} / \mathrm{DAPI}^{-}$blocks, orange arrows indicate $\mathrm{CMA}_{3}{ }^{+}$blocks, and red arrows indicate $45 \mathrm{~S}$ rDNA sites

\section{Location of 45S rDNA sites}

The application of FISH to localize the 45S rDNA sites allowed for the visualization of $45 \mathrm{~S}$ rDNA in pairs of chromosomes (three, four or five, depending on the species), along with terminal $45 \mathrm{~S}$ rDNA hybridization sites (Figs. 1 and 2). The karyotypes of the species $C$. macrophyllum, Po. pluviosa and L. ferrea each had three chromosome pairs with $45 \mathrm{~S}$ rDNA hybridization sites 
(Fig. 1). The species Po. bracteosa, Po. laxiflora, Po. microphylla, Ca. pulcherrima and Po. pyramidalis each had four chromosome pairs with $45 \mathrm{~S}$ rDNA sites (Fig. 2). Five chromosome pairs with hybridization sites for $45 \mathrm{~S}$ rDNA were observed in E. calycina (Fig. 1f) and Pa. echinata (Fig. 2r).

All species demonstrated 45S rDNA hybridization sites in the fourth chromosome pair, and only Ca. pulcherrima did not show a marking on the seventh chromosome pair. The $45 \mathrm{~S}$ rDNA hybridization sites in the eighth and tenth chromosome pairs were limited to Po. microphylla and Po. pyramidalis, respectively. The most frequent markers were located in the second chromosome pair (E. calycina, L. ferrea and Po. pyramidalis), in the fifth chromosome pair (E. calycina, Po. bracteosa and Po. microphylla) and in the eleventh chromosome pair (E. calycina, Pa. echinata and Ca. pulcherrima).

\section{Analysis of the 2C DNA}

The histograms in Fig. 3 show the fluorescence distribution as a function of the number of nuclei in the examined sample (Fig. 3). The $\mathrm{Pa}$. echinata large-leaf variant (LV) was the taxon with the highest $2 \mathrm{C}$ value of DNA (2.82 pg). The Pa. echinata LV was then used as the reference for high DNA content; compared to this reference value, the DNA content of the other species was lower by $46.3 \%$ for L. ferrea, $45.4 \%$ for E. calycina, $42.2 \%$ for Ca. pulcherrima, 35.1\% for C. macrophyllum, 33.7\% for Po. microphylla, 33.3\% for Po. pluviosa, $32.6 \%$ for Po. laxiflora, $31.9 \%$ for Po. bracteosa and Po. pyramidalis, $2.1 \%$ for the Pa. echinata small-leaf variant (SV), and $0.4 \%$ for the Pa. echinata medium-leaf variant (MV).

The ANOVA for the 2C DNA of the species revealed a highly significant difference, with a low coefficient of variation: $1.45 \%$ (Table 2). The Scott-Knott test clustered the taxa into six groups based on the average $2 \mathrm{C}$ values, with a minimum significant difference of 0.0647 (Table 1). Species from the genus Poincianella were arranged into group C. Two species remained in isolated groups: E. calycina and C. macrophyllum. The species $L$. ferrea and $\mathrm{Ca}$. pulcherrima were placed in group $\mathrm{E}$.

An ANOVA was carried out to estimate the variation of the DNA content for only the three morphotypes of $\mathrm{Pa}$. echinata, thus demonstrating the existence of a significant difference at $p$-value $=<0.05$ (Table 3). The Scott-Knott test with only the morphotypes of $\mathrm{Pa}$. echinata showed a separation between the morphotypes, as the SV type was isolated in group B with a statistically significant difference in relation to the MV and LV types in group A.

\section{Discussion}

Prior studies have been carried out to locate heterochromatin rich in AT and $\mathrm{GC}$ among species from the Caesalpinia group using the fluorochromes $\mathrm{CMA}_{3}$ and

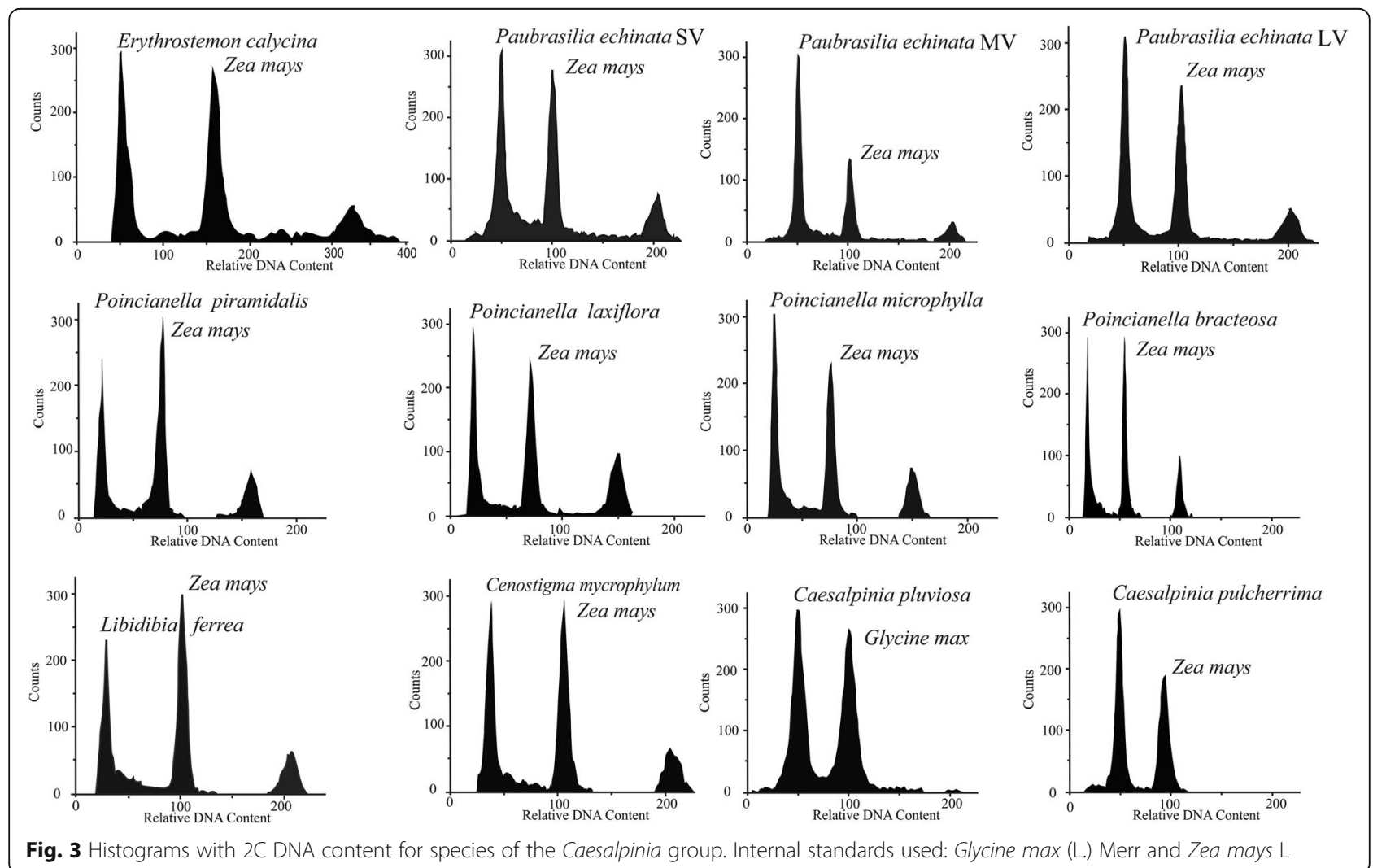


Table 2 Summary of the ANOVA for the characteristic 2C DNA content among the analyzed species

\begin{tabular}{lll}
\hline Sources of variation & GL & QM \\
\hline Taxon & 11 & $1.136674^{a}$ \\
Error & 48 & 0.000888 \\
CV (\%) & 1.46 & \\
\hline
\end{tabular}

${ }^{a}$ significant at $1 \%$ probability by $\mathrm{F}$ test

GL Level of freedom, QM Average square, CV Coefficient of variation

DAPI. Previous studies in the Senna and Chamaecrista genera revealed the presence of $\mathrm{CMA}_{3}{ }^{+} / \mathrm{DAPI}^{-}$and small $\mathrm{CMA}_{3}{ }^{-} / \mathrm{DAPI}^{+}$terminal or subterminal blocks [14]. In Copaifera, only $\mathrm{CMA}_{3}{ }^{+} / \mathrm{DAPI}^{-}$blocks were observed [24], similar to the terminal pattern observed in the present study, for which the analyzed species showed heterochromatin blocks that were rich in $\mathrm{GC}$ and poor in $\mathrm{AT}$. These $\mathrm{CMA}_{3}{ }^{+} / \mathrm{DAPI}^{-}$bands have been observed only in the terminal regions of chromosomes and have ranged from two to four pairs of chromosomes in the analyzed species. Additionally, $\mathrm{CMA}_{3}{ }^{+}$blocks have been observed in the metaphase chromosomes of $L$. ferrea and Po. microphylla, indicating either the existence of GC-rich pericentromeric sequences in related genera (suggesting a shared trait with a common ancestor) or changes related to the composition of centromeric satellite DNA, which is qualitatively rich in GC in these species.

Fluorochrome $\mathrm{CMA}_{3}{ }^{-} / \mathrm{DAPI}^{+}$blocks have already been observed in Senna obtusifolia (L.) H.S. Irwin \& Barneby and in one population of Chamaecrista nictitans Moench [14]. However, these bands were not reported in the present study. The absence of this type of heterochromatin may be a typical characteristic of species in the analyzed genera of Poincianella, Libidia, Erytrostemon, Paubrasilia, Caesalpinia and Cenostigma. However, the karyotype characterization on more population can relieve the interspecific variation in cytogenetic markers. In the Leguminosae family, various patterns of AT-rich and GC-poor heterochromatin were also observed for the Mimosa [25] and Erythrina [26] genera. These variations reinforce the need to characterize heterochromatin in other species so as to understand the distribution pattern and evolution of this class of DNA, which is variously colored within the Caesalpinia group.

In the present study, $\mathrm{CMA}_{3}{ }^{+} / \mathrm{DAPI}^{-}$terminal blocks coincided with certain $45 \mathrm{~S}$ rDNA hybridization sites,

Table 3 Summary of the ANOVA for 2C DNA content among the three morphological leaf variants of Paubrasilia echinata

\begin{tabular}{lll}
\hline Sources of variation & $\mathrm{GL}$ & $\mathrm{QM}$ \\
\hline Taxon & 2 & $0.012653^{\mathrm{a}}$ \\
Error & 12 & 0.012640 \\
$\mathrm{CV}(\%)$ & 1.16 & \\
\hline
\end{tabular}

${ }^{\mathrm{a}}$ significant at $5 \%$ probability by $\mathrm{F}$ test

GL Level of freedom, QM Average square, CV Coefficient of variation reinforcing the fact that these $\mathrm{CMA}_{3}{ }^{+}$blocks relate to these $45 \mathrm{~S}$ rDNA, which in turn are rich in $\mathrm{GC}$ bases [27-29]. However, the application of base-specific fluorochromes did not reveal rDNA sites with few repetitions, as the small heterochromatic block made detection and photographic documentation unviable for the epifluorescence microscope [30].

Molecular cytogenetics techniques have been widely used to localize specific in situ DNA sequences [31]. Genetically related species tend to have karyotypes with similar characteristics in terms of sequence localization and are useful in studies of plant systematics, taxonomy and evolution mainly contributing to groupings of species or cytotypes that share common characteristics, thus suggesting primitiveness or deactivation for a given cytological marker that is shared among a group of plants [32-38].

The hybridization sites of $45 \mathrm{~S}$ rDNA probes in species of the Caesalpinia group have shown variations in both the number and the location of these sequences. The differences in the number of such sequences generally occur due to chromosomal rearrangements such as translocations, inversions, duplications and deletions [39], whereas variations in the signal intensity of hybridization are observed between sites with different numbers of rDNA replicates. Any changes in these sites' patterns of distribution are levels of speciation; this may assist in determining how evolution has occurred within a group of taxonomically complex plants $[31,40]$. Lower quantitative variation has been observed in the Poincianella genus, suggesting greater stability in the number of $45 \mathrm{~S}$ rDNA sites (a total of eight). Conservation in the location of the rDNA genes (as revealed using FISH) was observed for species from the genus Trifolium (Leguminosae: Papilionoideae), which may indicate that some Leguminosae have great stability in this region [41]. This stability, which is based on the number and location of a chromosomal marker, is a good characteristic for species identification and delimitation through karyotype analysis.

The species in this study showed significant variations in 2C DNA and, consequently, in the size of the genomes for the evaluated species and genera. In addition, the low coefficient of variation among the replicates indicates the precision of the sample, as analyzed using flow cytometry. The variation in the amount of DNA across species can be attributed to the loss or gain of DNA sequences, which usually consist of repetitive DNA; this may occur due to evolutionary changes in accumulation and/or loss of repeating monomers in the micro and macro environments during the species' evolution $[42,43]$. This suggests that such losses or additions to the genome become stabilized during microevolution and selection [43]. 
In this work, only Ca. pulcherrima had a lower estimated amount of $2 \mathrm{C}$ DNA (1.63 pg) than its previous estimate $(1.80 \mathrm{pg})$ [16]. This may be due to the variation in number of chromosomes for the two analyzed populations of Ca. pulcherrima, as the population evaluated in this study presented $2 n=24$, but the population evaluated by OHRI et al. [16] presented $2 n=28$. The estimated DNA nuclear content for diploid Ca. crista $(2 n=24)$ indicated a too-high value of $0.707 \mathrm{pg}$ per chromosome, which leads to $17.67 \mathrm{pg}$ for the $2 \mathrm{C}$ DNA. This value, which is much higher than our result, can be attributed to the different cytophotometric methods, as Allium cepa L.'s DNA value was computed as a DNA size pattern [17]. The $2 \mathrm{C}$ value that we found for Ca. crista was also considerably higher than those that OHRI et al. [16] found for the species in the genus Caesalpinioideae. Analyzing the DNA content and chromosomal differences observed for taxa from the Caesalpinia genus, together with the results from the literature, requires an interdisciplinary mode in order to indicate the species' taxonomy, delimitation and clustering.

Many species in the Caesalpinia group exhibit a high degree of phenotypic plasticity, especially in foliage and leaflets. This has resulted in multiple nomenclature for the species, with each leaf-size variant having a specific condition, thus resulting in taxonomic problems $[1,5,7,9]$. This fact can be observed in Pa. echinata, which was previously arranged in the Caesalpinia genus and which has three morphotypes that were previously characterized using chloroplast DNA sequences [44]. The three morphotypes (leaf-size variants) presented small variations in 2C DNA, with values of $2.76,2.81$ and $2.82 \mathrm{pg}$ for the SV, MV and LV types, respectively. The Scott-Knott test separated these morphotypes into two groups, one with only $\mathrm{Pa}$. echinata $\mathrm{SV}$ and one composed of $\mathrm{Pa}$. echinata MV and LV; this shows that, although the variations among $\mathrm{Pa}$. echinata leaf-size morphotypes are not large, the values are sufficient to separate the SV morphotype from the other two variants, with this type's low DNA content acting as a differentiating feature.

In legume species, a positive correlation has been observed between leaf size and nuclear DNA content [45]. This relationship was also observed in this study, wherein the variants with the relatively large leaves (MV and LV) had more DNA than the SV variants. Therefore, diversification of genome size results from speciation, which, along with phenotypic changes in quantitative descriptors, is an adaptation response such as the ones observed in polyploid plants [46]. Thus, plants' 2C DNA can be used to estimate the taxonomic differentiation between species, as seen here for the variants of Pa. echinata.

The data obtained in our studies corroborate the new classification of the species that were initially placed in the Caesalpinia group [5, 9-11], showing that the species that had at least $1.87 \mathrm{pg}$ of $2 \mathrm{C}$ DNA in this study should actually be grouped in the Poincianella genus. Among the species analyzed in the present study, the only representative of the Erythrostemon genus was E. calycina, which had the least amount of 2C DNA (1.54 pg) and which was also the only species to present five pairs of chromosomes with the presence of $45 \mathrm{~S}$ rDNA sites; these were unique characteristics of this genus. In previous analyses, similarities in chromosome morphology have been reported for the six species studied herein, and karyotype formulas have shown the predominance of metacentric chromosomes [47].

Only one species was evaluated for the Cenostigma genus, C. macrophyllum; this species which was initially collected under the belief that it belonged to the Caesalpinia genus. The similarities between species of these two genera have also been visualized previously, as the species Cenostigma sclerophyllum Tul. was later described as a synonym for Caesalpinia marginata Tul. $[8,48]$. The analyses of C. macrophyllum enabled us to observe that it was the only species to present only six $\mathrm{CMA}_{3}{ }^{+/} \mathrm{DAPI}^{-}$ bands, showing that the amount of GC-rich heterochromatin was lower than that of the other species evaluated herein; this could be a feature exclusive to the Cenostigma genus.

In this work, the distribution pattern for heterochromatin, the physical location of $45 \mathrm{~S}$ rDNA regions and the amount of DNA were all useful to corroborate studies of systematics and of evolution in Caesalpinia-group species. Although the quantity of species evaluated herein is only a small fraction of the diversity already described as belonging to the Caesalpinia group, and although some species were relocated within new genera, it was possible to observe a distinctive pattern for individual cytogenetic characteristics in the genera currently specified as Poncianella. This shows that the karyotypic analysis and the quantification of $2 \mathrm{C}$ DNA are valid methods to support taxonomic and biosystematics studies.

\section{Conclusion}

The quantitative variation in GC-rich heterochromatin among species in the Caesalpinia group indicates not only the variable number of satellite-related rDNA sites but also the existence of chromosomes with pericentromeric repetitive DNA with GC-rich heterochromatin in L. ferrea and Po. microphylla species. The intra- and interspecific variations in size of the GC-rich chromosomal blocks related to rDNA and satellites (relative to the location of these regions), as determined using the FISH technique with a probe for $45 \mathrm{~S}$ rDNA. This relation suggests that the use of fluorochromes for the localization of $45 \mathrm{~S}$ rDNA is not indicated for loci numbers identification in species of the Caesalpinia group. This fact is attributed to the minor size replications of the $45 \mathrm{~S} \mathrm{rDNA}$ genes in 
some chromosomes, which make it difficult to observe variations using $\mathrm{CMA}_{3}$ fluorochromes. The $2 \mathrm{C}$ DNA may not be even related to morphological leaf size for Paubrasilia echinata, so this relationship must be evaluated again with other populations to increase the number of analyzed plants. On the other hand, the 2C DNA helped us to see all the variation in the Caesalpinia group within this trait. All the data indicate that the actual taxonomy appropriated by the Caesalpinia group is due to the larger chromosomal and genome-size variations, which could be clustered in a specific genus. This information shows the group from point of view that differs from the old taxonomy, which grouped all species analyzed herein as just one genus.

\section{Abbreviations}

2C DNA: 2C DNA content; 2n: Diploid number; ANOVA: Analysis of variance: $\mathrm{CMA}_{3}$ : Chromomycin $\mathrm{A}_{3}$; DAPI: 4'-6-diamidino-2-phenylindole; FISH: Fluorescent in situ hybridization; LV: Large-leaf variant; MV: Medium-leaf variant; rDNA: Ribosomal DNA: SSC: Salt sodium citrate; SV: Small-leaf variant

\section{Acknowledgments}

The authors would like to thank José Lima Paixão, a technician who assisted in the collection and identification of the botanical material, as well as the collaborators at the herbarium of Universidade Estadual de Feira de Santana for confirming the identification of the Cenostigma species.

\section{Funding}

This research received financial support from Conselho Nacional de Desenvolvimento Científico e Tecnológico (CNPq) (Grant number 473393/ 2007-7) and Coordenação de Aperfeiçoamento de Pessoal de Nível Superior (CAPES) for the collection of germoplasm and for the acquisition of laboratory supplies for the analysis. The cytogenetics techniques were performed at the Plant Breeding Laboratory at Universidade Estadual de Santa Cruz, which provided the financial support for the equipment and physical structures used in this study.

\section{Availability of data and materials}

All data sets that support this article's conclusions are included in the article.

\section{Authors' contributions}

PSR performed the cytogenetic laboratory procedures and prepared the manuscript text. RXC helped write and review the text and made several contributions on the relations between plants, as well as obtaining financial support. CAFM helped with the cytogenetic procedures, analyzed the results and reviewed the text. TNSP helped with the flow cytometry procedure and the data interpretation. MMS participated in the molecular cytogenetic analysis and helped with the data interpretation and the protocol adjustment. All authors have read and approved the manuscript and consent to its publication.

\section{Ethics approval and consent to participate}

Permission for seeds collection was not necessary because the collections were made in public areas. We also found some species near roads and in rural areas. Taxonomists at the herbarium museums of Universidade Estadual de Santa Cruz (Prof. Dr. André Márcio Araújo Amorim) and Universidade Estadual de Feira de Santana (Prof. Dr. Luciano Paganucci de Queiroz) certified all species in Bahia, Brazil.

\section{Consent for publication}

Not applicable.

\section{Competing interests}

The authors declare that they have no competing interests.

\section{Publisher's Note}

Springer Nature remains neutral with regard to jurisdictional claims in published maps and institutional affiliations.

\section{Author details}

'Departamento de Ciências Biológicas, Centro de Biotecnologia e Genética, Universidade Estadual de Santa Cruz, Rodovia Jorge Amado, km 16, CEP, Ilhéus, BA 45662-900, Brazil. ² Centro de Ciências e Tecnologias Agropecuárias, Laboratório de Melhoramento Genético Vegetal, Universidade Estadual do Norte Fluminense, Campos dos Goytacazes, Brazil.

Received: 15 September 2017 Accepted: 29 March 2018

Published online: 11 April 2018

\section{References}

1. Lewis GP, Schrire B, Mackinder B, Lock M. Legumes of the world. Kew: Roy Bot Gard; 2005. p. 577.

2. Herendeen PS. Structural evolution in the Caesalpinioideae (Leguminosae). In: Herendeen PS, Bruneau A, editors. Advances in Legume Systematics, part 9. Kew: Roy Bot Gard, 2000. p. 45-64

3. Barroso GM, Peixoto AL, Costa GC, Ichasso CLF, Guimarães EF, Lima HC. Sistemática de angiospermas do Brasil, vol. 337. Viçosa: UFV; 1984.

4. Bortoluzzi RLC, Biondo E, Miotto STS, Schifino-Witmann MT. Abordagens taxonômicas e citogenéticas em Leguminosae-Caesalpinioideae na região sul do Brasil. Revista Brasileira de Biociências. 2007;5:339-41.

5. Gagnon E, Bruneau A, Hughes CE, Queiroz LP, Lewis GP. A new generic system for the pantropical Caesalpinia group (Leguminosae). PhytoKeys. 2016;71:1-160

6. IUCN. IUCN red list of threatened species; 2013.

7. Polhill R, Vidal J. Caesalpinieae. In: Polhill R, Raven PH, editors. Advances in legume systematics, part 1. Richmond: Roy Bot Gard; 1981. p. 81-95.

8. Lewis GP. Caesalpinia, a revision of the Poincianella - Erythrostemon group. Kew: Roy Bot Gard; 1998

9. Gagnon E, Lewis GP, Sotuyo JS, Hughes CE, Bruneau AA. Molecular phylogeny of Caesalpinia sensu lato: increased sampling reveals new insights and more genera than expected. S Afr J Bot. 2013;89:111-27.

10. Queiroz LP. Leguminosas da Caatinga. Feira de Santana: Universidade Estadual de Feira de Santana. Associação Plantas do Nordeste; 2009.

11. Queiroz LP. New combinations in Libidibia (DC.) Schltdl. And Poincianella Britton \& Rose (Leguminosae, Caesalpinioideae). Neodiversity. 2010;5:11-2.

12. Melo CAF, Martins MIG, Oliveira MBM, Benko-Iseppon AMR, Carvalho R. Karyotype analysis for diploid and polyploid species of the Solanum L. Plant Syst Evol. 2011;293:227-35.

13. Kron P, Suda J, Husband BC. Applications of flow cytometry to evolutionary and population biology. Annu Rev Ecol Evol Syst. 2007;38:847-76.

14. Soares-Scott MD, Meletti LMM, Bernacci LC, Passos IRS. Citogenética clássica e molecular em passifloras. In: Faleiro FG, Souza MGC, BenkoIseppon AM. Cytogenetics and chromosome banding patterns in Caesalpinioideae and Papilionioideae species of Pará, Amazonas, Brazil. Bot J Linn Soc. 2004;144:181-91.

15. Héla EFO, Naghmouchi S, Walker DJ, Correal E, Boussaïd M, Khouja ML. Variability in the pod and seed parameters and nuclear DNA content of Tunisian populations of Ceratonia siliqua L. Caryologia. 2008;61(4):354-62.

16. Ohri D, Kumar A, Pal M. Correlations between 2 C DNA values and habit in Cassia (Leguminosae: Caesalpinioideae). Plant Syst Evol. 1986;153:223-7.

17. Jena S, Sahoo P, Mohanty S, Das AB. Identification of RAPD markers, in situ DNA content and structural chromosomal diversity in some legumes of the mangrove flora of Orissa. Genetica. 2004;122:217-26.

18. Johansen DA. Plant Microtechique. New York: McGraw-Hill Book Company; 1940

19. Guerra M, Souza MJ. Como observar cromossomos: Um guia de práticas em citogenética vegetal, animal e humana. Ribeirão Preto: Editora Funpec; 2002.

20. Souza MM, Urdampilleta JD, Forni-Martins ER. Improvements in cytological preparations for fluorescent in situ hybridization in Passiflora. Genet Mol Res. 2010;9(4):2148-55.

21. Dolezel J, Greilhuber J, Lucretti S, Meister A, Lysa KMA, Nardi L, Obermayer R. Plant genome size estimation by flow cytometry: inter-laboratory comparison. Ann Bot. 1998:82:17-26.

22. Dolezel J, Gohde W. Sex determination in dioecious plants Melandrium album and M. Rubrum using high-resolution flow cytometry. Cytometry. 1995;19:103-6. 
23. Ferreira DF. Programa Sisvar. Software 5.0: UFLA; 2003.

24. Gaeta ML, Yuyama PM, Sartori D, MHP F, ALL V. Occurrence and chromosome distribution of retroelements and NUPT sequences in Copaifera langsdorffii Desf. (Caesalpinioideae). Chromosom Res. 2010;18:515-24.

25. Sousa SM, Reis AC. Viccini. Polyploidy, B chromosomes, and heterochromatin characterization of Mimosa caesalpiniffolia Benth. (Fabaceae-Mimosoideae). Tree Genet Genomes. 2013;9:613-9.

26. Silva SC, Martins MIG, Santos RC, Peñaloza APS, Melo-Filho PA, Benko-lseppon A, Valls JFM, Carvalho R. Karyological features and banding patterns in Arachis species belonging to the Heteranthae section. Plant Syst Evol. 2010;285:201-7.

27. Schweizer D. Fluorescent chromosome banding in plants: application, mechanisms, and implications for chromosome structure, Proceedings of the fourth John Innes symposium, held September; 1979. p. 61-72.

28. Sumner AT. Chromosome banding. London: Unwin and Hyman; 1990.

29. Robledo G, Seijo G. Species relationships among the wild B genome of Arachis species (section Arachis) based on FISH mapping of rDNA loci and heterochromatin detection: a new proposal for genome arrangement Theor Appl Genet. 2010;121(6):1033-46.

30. Melo CAF, Souza MM, Abreu PP, Viana AJC. Karyomorphology and GC-rich heterochromatin pattern in Passiflora (Passifloraceae) wild species from Decaloba and Passiflora subgenera. Flora. 2014:209:620-31.

31. Schwarzacher T, Leitch AR, Heslop-Harrison JS. DNA : DNA in situ hybridization and methods for light microscopy. In: Harris N, Oparka KJ, editors. Plant cell biology: a practical approach. Oxford: Oxford University Press; 1994. p. 127-55.

32. Maluszynska J, Heslop-Harrison JS. Physical mapping of rDNA loci in Brassica species. Genome. 1993;36:774-81.

33. Galasso I, Pignone D, Frediani M, Maggiani M. Chromatin characterization by banding techniques, in situ hybridization, and nuclear DNA content in Cicer L. (Leguminosae). Genome. 1996;39:258-65.

34. Thomas HM, Harper JÁ, Meredith MR, Morgan WG, Thomas ID, Timms E, King IP. Comparison of ribosomal DNA sites in Lolium species by fluorescente in situ hibridization. Chromosom Res. 1996:4:486-90.

35. Zhang D, Sang T. Physical mapping of ribosomal RNA genes in peonies (Paeonia, Paeoniaceae) by fluorescent in situ hybridization and concert evolution. Am J Bot. 1999:85:735-40.

36. Seijo JG, Lavia Gl, Fernández A, Krapovickas A, Ducasse D, Shan F, Yan G, Plummer JA. Karyotype evolution in the genus Boronia (Rutaceae). Bot J Linn Soc. 2003;142:309-20.

37. Sede SM, Fortunato RH, Poggio L. Chromosome evaluation of southern south American species of Camptosema and allied genera (DiocleinaePhaseolae-Papilionoideae-Leguminosae). Bot J Linn Soc. 2006;52:235-43.

38. Robledo G, Seijo G. Characterization of the Arachis (Leguminosae) D genome using fluorescence in situ hybridization (FISH) chromosome markers and total genome DNA hybridization. Genet Mol Biol. 2008;31(3):717-24.

39. Moscone EA, Klein F, Lambrou M, Fuchs J, Schweizer D. Quantitative karyotyping and dual-color FISH mapping of 5 S and 18S-25S rDNA probes in the cultivated Phaseolus species (Leguminosae). Genome. 1999:42(6):1224-33,

40. JS H-H. Comparative genome organization in plants: from sequence and markers to chromatin and chromosomes. Plant Cell. 2000;12:617-35.

41. Ansari HA, Ellison NW, Reader SM, Badaevas ED, Friebe B, Miller TE, Williams WM. Molecular cytogenetic of $5 \mathrm{~S}$ and 18S-26S rDNA loci in white clover (Trifolium repens L.) and related species. Ann Bot. 1999;83:199-206.

42. Price HJ. Nuclear DNA content variation within angiosperm species. Evolution Trends. 1998; 1 (2):53-60.

43. Mohanty S, Das AB. Interespecific genetic in 15 species of Cassia L. evident by chromosome and 4C nuclear DNA analysis. J Biolo Sci. 2006;6(4):664-70.

44. Juchum FS. Phylogenetic relationships among morphotypes of Caesalpinia echinata lam. (Caesalpinioideae: Leguminosae) evidenced by trnL intron sequences. Naturwissenschaften. 2008;95:1085-91.

45. ChungJ LH, Arumuganathan K, Graef GL, Specht JE. Relationships between nuclear DNA content and seed and leaf size in soybean. Theo Appl Genet. 1998:96:1064-8.

46. Sugiyama S-I. Polyploidy and cellular mechanisms changing leaf size: comparison of diploid and autotetraploid populations in two species of Lolium. Ann Bot. 2005;96:931-8

47. Rodrigues PS, Souza MM, Correa RX. Karyomorphology and karyotype asymmetry in the south American Caesalpinia species (Leguminosae and Caesalpinioideae). Genet Mol Biol. 2014;13:8278-93.

48. Warwick MC, Lewis GP. A revision of Cenostigma (Leguminosae Caesalpinioideae - Caesalpinieae), a genus endemic to Brazil. Kew Bull. 2009;64:135-46

\section{Submit your next manuscript to BioMed Central and we will help you at every step:}

- We accept pre-submission inquiries

- Our selector tool helps you to find the most relevant journal

- We provide round the clock customer support

- Convenient online submission

- Thorough peer review

- Inclusion in PubMed and all major indexing services

- Maximum visibility for your research

Submit your manuscript at www.biomedcentral.com/submit
Biomed Central 